\title{
Social patterns of pay systems and their associations with psychosocial job characteristics and burnout among paid employees in Taiwan ${ }^{\text {is }}$
}

\author{
Wan-Yu Yeh ${ }^{\mathrm{a}, \mathrm{b}}$, Yawen Cheng ${ }^{\mathrm{a}, *}$, Chiou-Jung Chen ${ }^{\mathrm{c}}$ \\ a Institute of Health Policy and Management, College of Public Health, National Taiwan University, 17 Xu-Zhou Road, Taipei 100, Taiwan \\ ${ }^{\mathrm{b}}$ Institute of Occupational Medicine and Industrial Hygiene, College of Public Health, National Taiwan University, Taipei, Taiwan \\ ${ }^{c}$ Institute of Occupational Safety and Health, Council of Labor Affairs, Taipei, Taiwan
}

\section{A R T I C L E I N F O}

\section{Article history:}

Available online 5 March 2009

\section{Keywords:}

Pay system

Burnout

Job stress

Survey

Taiwan

\begin{abstract}
A B S T R A C T
Today, performance-based pay systems, also known as variable pay systems, are commonly implemented in workplaces as a business strategy to improve workers' performance and reduce labor costs. However, their impact on workers' job stress and stress-related health outcomes has rarely been investigated. By utilizing data from a nationally representative sample of paid employees in Taiwan, we examined the distribution of variable pay systems across socio-demographic categories and employment sectors. We also examined the associations of pay systems with psychosocial job characteristics (assessed by Karasek's Demand-Control model) and self-reported burnout status (measured by the Chinese version of the Copenhagen Burnout Inventory). A total of 8906 men and 6382 women aged 25-65 years were studied, and pay systems were classified into three categories, i.e., fixed salary, performance-based pay (with a basic salary), and piece-rated or time-based pay (without a basic salary). Results indicated that in men, $57 \%$ of employees were given a fixed salary, $24 \%$ were given a performance-based pay, and $19 \%$ were remunerated through a piece-rated or time-based pay. In women, the distributions of the 3 pay systems were $64 \%, 20 \%$ and $15 \%$, respectively. Among the three pay systems, employees earning through a performance-based pay were found to have the longest working hours, highest level of job control, and highest percentage of workers who perceived high stress at work. Those remunerated through a piecerated/time-based pay were found to have the lowest job control, shortest working hours, highest job insecurity, lowest potential for career growth, and lowest job satisfaction. The results of multivariate regression analyses showed that employees earning through performance-based and piece-rated pay systems showed higher scores for personal burnout and work-related burnout, as compared to those who were given fixed salaries, after adjusting for age, education, marital status, employment grade, job characteristics, and family care workloads. As variable pay systems have gained in popularity, findings from this study call for more attention on the tradeoff between the widely discussed management advantages of such pay systems and the health burden they place on employees.
\end{abstract}

(c) 2009 Elsevier Ltd. All rights reserved.

\section{Introduction}

Pay has always been one of the most sensitive issues in employment relationships. As market competition intensifies, many enterprises are under pressure to rearrange their pay strategies. Performance-based pay systems (also known as variable pay

\footnotetext{
is This study was supported by the Institute of Occupational Safety and Health Council of Labour Affairs, and research grants from the National Science Council (NSC95-2314-B002-245)

* Corresponding author. Institute of Health Policy and Management, College of Public Health, National Taiwan University, 17 Xu-Zhou Rd., Taipei 100, Taiwan. Tel.: +886 23366 8056; fax: +886223215048.

E-mail address: ycheng@ntu.edu.tw (Y. Cheng).
}

systems), which tie rewards to employee output more closely than fixed pay systems, have been advocated as efficient business strategies to promote desired work attitude and performance, as well as to reduce labor costs (Kurdelbusch, 2002; Lawler, 1990). At the policy level, performance-based pay systems have also been promoted as a means to increase employment opportunities (Cowling, 2000, 2002). However, performance-based pay systems often come with a greater extent of performance evaluation and a more competitive work climate, and thus might have deleterious impacts on employees' well-being.

Performance-based pay systems encompass all forms of pay that are not held to a fixed amount, and they are designed primarily to achieve and reinforce organizations' for-profit objectives (Lawler, 1990). Among all possibilities, piece-rate pay without any basic 
salary might be the most typical one. Other forms of performancebased pay systems include those that are tied to the performance of individual workers, group units, or that of the whole company, either through profit-sharing, annual bonuses, or employee ownership plans (Howard, 2004; Kurdelbusch, 2002). These pay systems usually include a basic salary. Some recent surveys have indicated that performance-based pay systems were common in both developing and developed countries (Hansen, 2006; Kurdelbusch, 2002; Watson Wyatt, 2005). However, the potential for an adverse impact on job conditions and workers' health has rarely been studied.

As illustrated in Fig. 1, we postulate that external macroeconomic and social conditions-such as the growing dominance of service sectors, intensified market globalization, and changes in employment relationship and related policies-might push organizations to adopt more cost-efficient management strategies, including performance-based pay systems. Such pay systems might adversely affect employees' health and well-being in the following two ways: (1) psychosocial and behavioral responses and (2) changes in work arrangements.

\section{Psychosocial and behavioral responses}

From management's perspective, one of the primary purposes of applying variable pay systems is to create an active work climate, in which employees gain a sense of ownership and self-control and are motivated to achieve higher levels of work performance (Lawler, 1990). In Burawoy's classic sociological study of labor process, he elaborated on how the design of pay systems affected workers' motivation, work behavior, and even self-identity. With the design of variable pay systems, employers were able to align conflicting interests of workers with that of employers and motivate workers to actively cooperate with the management. Individual-based pay systems also led to a more individualized work environment, in which workers were made to compete with each other. Burawoy concluded that with the manipulation of pay systems, workers' collective consciousness against management's control had been greatly dissolved (Burawoy, 1979). We hypothesize that employees with performance-based pay systems might be more motivated but they will also be more competitive, and will thus be prone to stress-related illnesses. Some empirical studies have been supportive of this theory. For example, an experimental study of 45 professional typists found a significant increase in blood pressure when study subjects were given monetary incentives during data entry task tests (Schleifer \& Okogbaa, 1990). In several surveys conducted with blue-collar workers, those with performancebased pay were found to have higher levels of depression and more somatic health complaints and workplace injuries than workers with fixed pays (Kaminski, 2001; Landsbergis, Cahill, \& Schnall, 1999; Shirom, 1999).

\section{Changes in work arrangements}

In addition to its psychosocial effects, the adaptation of performance-based pay systems may entail adverse changes in working arrangements, including heavier workloads, higher work pace and tighter performance evaluation. The effects on workers' job control are more controversial, however. Workers with performance-based pay might be given greater job autonomy and a sense of empowerment (Cowling, 2000; Kanawaty, 1992). On the other hand, it has been argued that without representative participation and industrial democracy, performance-based pay will only enhance the power of management and weaken workers' collective power. Performance-based pay systems might also further worsen the existing social inequalities in working conditions, including work hazards and work rewards. For example, pay flexibility may favor those who play central roles in organizations; while for peripheral workers whose skills are more replaceable, pay flexibility would entail worsened working conditions and greater employment insecurity.

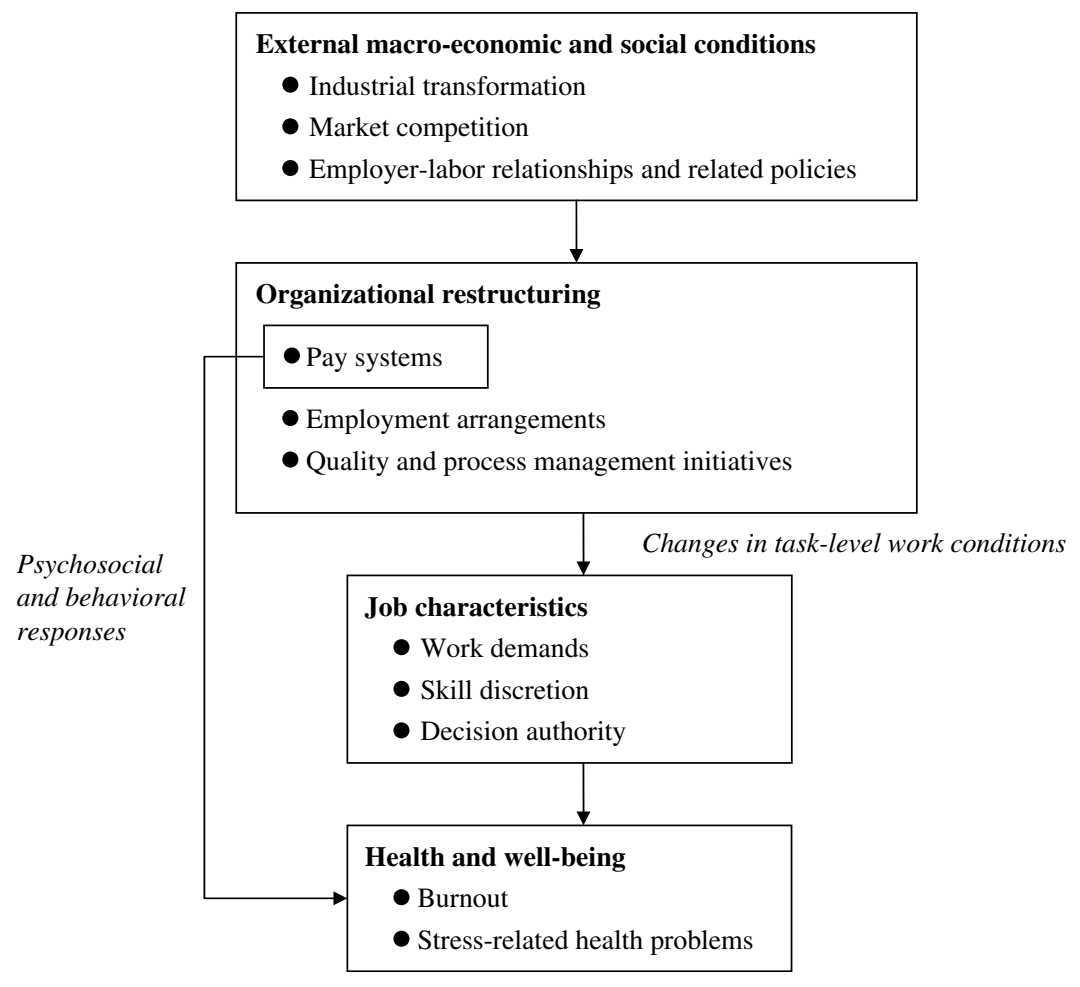

Fig. 1. Conceptual model linking pay system with workers' health and well-being. 
Concerns about the adverse health impacts of labor flexibility strategies have increased, such as precarious employment, multiskilling, and subcontracting (Mayhew, Quintan, \& Ferris, 1997; Menendez, Benach, Muntaner, Amable, \& O'Campo, 2007; Schabracq \& Cooper, 1997). Until now, however, few studies have been carried out to investigate the effects of pay flexibility on employees' work conditions and health, and even fewer have been conducted in a wider range of occupations that include both the industrial and service sectors (Kaminski, 2001; Landsbergis et al., 1999; Shirom, 1999).

By utilizing data from a national survey of representative Taiwanese paid employees, we first aimed to investigate the prevalence and distribution of performance-based pay systems across various demographic and employment groups of general paid employees in Taiwan. Secondly, we examined the association of different pay systems with workers' job characteristics, perceived job insecurity and job satisfaction. Thirdly, we examined the associations of variable pay systems with burnout status. In this study, we chose burnout as an indicator of employees' health status, as it is considered an antecedent to various stress-related health outcomes (Maslach, Schaufeli, \& Leiter, 2001; Shirom, Melamed, Toker, Berliner, \& Shapira, 2005).

\section{Methods}

\section{Study population and procedures}

The Institute of Occupational Safety and Health (IOSH) of the Taiwanese government had conducted several nationwide surveys concerning occupational safety and health. Data for this study were from a cross-sectional survey conducted in September 2004. A representative sample of paid employees in Taiwan was selected by a two-stage random sampling scheme. At the first stage, all districts (in urban areas) and villages (in rural areas) were grouped into 24 urbanization levels, and a sample of districts and villages was randomly selected from each level. At the second stage, a sample of households was randomly selected from each selected district or village; from selected households, all members aged 15 or above who were currently working as paid employees were identified and invited to participate in this survey.

Standardized self-administered questionnaires were delivered to each selected household by a trained interviewer; within a week, the same interviewer visited the household and collected the answered questionnaires with on-site checking. A total of 21,493 paid employees were identified, and among them, 17,321 (80.6\%) agreed to participate and finished the questionnaires. Main reasons for non-participation were failure to reach the selected subjects (42\%) and failure to retrieve the completed questionnaires from the subjects (38\%). However, background information for non-participants was not available. We restricted the study population to those aged between 25 and 65 years. In Taiwan, the labor participation rates for people younger than 25 and those older than 65 were $30 \%$ and 8\% (in 2004), respectively. People ranging in age from 25 to 65 years old accounted for about $90 \%$ of labor workforce. As a result, 15,288 participants (8906 men and 6382 women) were available for analysis. For more details concerning the sampling and survey procedures, please refer to our previous publication (Cheng, Chen, C. W., Chen, C. J., \& Chiang, 2005).

\section{Measures}

The questionnaire was designed to assess multiple dimensions of work conditions. In the questionnaire, pay systems were classified into three broad categories: (1) fixed monthly salary, which included only a fixed monthly pay and/or all kinds of fixed allowances; (2) performance-based pay, which included a monthly basic salary along with additional pay contingent upon the performance of individual worker, work unit, or organization; and (3) piece-rated or time-based pay without any basic pay (i.e., on a no-work-no-pay basis). Performance-based pay with a basic salary and piece-rate pay without a basic salary were differentiated in this study, even though the operation of piece-rate pay is also a form of performance-based pay.

Subjects were also asked to provide information regarding their working hours as well as their psychosocial work conditions. The average rate of working hours per week was measured by adding up all working hours during the week prior to the survey date. Shift work was measured by asking the subject if he/she was working shifts during the time period above. Psychosocial work demands ( 5 items) and job control ( 9 items) were assessed by the Chinese version of the Job Content Questionnaire (C-JCQ) based on Karasek's Job Strain model (Cheng, Luh, \& Guo, 2003; Karasek \& Theorell, 1990). This model postulates that a combination of high demands and low control causes high job strain and leads to negative health outcomes. The control dimension consists of two sub-components: decision authority and skill discretion. The model also postulates that demand-high control situations will enhance workers' active learning and lead to greater internal locus of control. Each item of the inventory was measured on a 4-point scale (strongly agree to strongly disagree). Detailed information regarding the psychometric properties of the C-JCQ can be found elsewhere (Cheng et al., 2003). In the present study, Cronbach's alpha coefficients for the job demands subscale were 0.31 for men and 0.39 for women, while those for the job control subscale were 0.87 for both men and women.

Along with the questionnaire, subjects were also asked to provide information about their job title, type of industry, ownership of work organization (private vs. public sector), and size of the organization's workforce. Taiwan's economy has been long dominated by small and median sized enterprises (SMEs) (Cheng et al., 2005; Small and Medium Enterprise Administration, 2006), which accounted for more than $97 \%$ of all enterprises. Measure of company size was included in analysis, because company size is presumably highly correlated to pay systems. On the other hand, we did not include employment tenure in analyses, because the measure does not adequately represent worker experiences in the labor market, considering the fact that the average life expectancy of SMEs in Taiwan is short (around 13 years in 2004) (Small and Medium Enterprise Administration, 2006) and worker's turnover rate is high. The average employment tenure of our study population was only 7.7 years.

Employment grade was classified in the following 6 categories, based on self-reported job titles, i.e., grade 1: administrators and managers; grade 2: professionals; grade 3: non-manual skilled; grade 4: non-manual low-skilled; grade 5: manual skilled; and grade 6: manual low-skilled. Industry type was divided into "manufacturing", "construction", "service", and "others".

Burnout status was assessed by the Chinese version of the Copenhagen Burnout Inventory (CBI) (Borritz \& Kristensen, 2001; Kristensen, Borritz, Villadsen, \& Christensen, 2005; Yeh, Cheng, Chen, Hu, \& Kristensen, 2007). With CBI, burnout is conceptualized as a state of physical and psychological fatigue and exhaustion, and three dimensions of burnout are identified according to the life domain from which burnout may arise: (1) personal or generic burnout ( 6 items), which is designed to measure the degree of burnout experienced by the person (e.g., "How often do you feel tired?"), regardless of his or her employment status (including unemployed, early retired, students, housewives, etc.); (2) workrelated burnout ( 7 items), which is designed to measure the degree of burnout perceived by the person at work as related to his or her 
work (e.g., "Do you feel burnt out because of your work?”); and (3) client-related burnout ( 6 items), which is designed to measure the degree of burnout perceived by the person as related to his or her work with clients (e.g., "Do you find it hard to work with clients?"), thus is suitable only for people whose work involve clients. The responses were recorded on a 5-point scale: from always (score $100)$ to never (0) or very seriously (100) to very slightly (0). In this survey, only the 'personal burnout' and 'work burnout' subscales of the CBI were used because of space limitation of the questionnaire. More information regarding the English version and the Chinese version of the $\mathrm{CBI}$, including the details of all subscales, items and calculation formula, can be found elsewhere (Borritz \& Kristensen, 2001; Yeh et al., 2007). In the 'work burnout' subscale, an item of the original C-CBI- "Do you have enough energy for family and friends during leisure time?"-was deleted in the analysis because it correlated poorly with the other items $(r<0.1)$. In the present study, Cronbach's alpha coefficients of the "personal burnout" subscale were above 0.93 and those of the "work burnout" were above 0.89 in both men and women.

Perceived job insecurity and career prospects were both assessed by a single item, asking subjects if they agreed with the statements, "my job is secure" and "my career prospect is good," respectively. The response was recorded on a four-point scale (strongly agree to strongly disagree) and were then re-coded dichotomously (agree/disagree). The level of self-rated job stress was assessed by the response to "How often do you feel very stressed at work?" in which the response was recorded on a fivepoint scale and then re-coded dichotomously (always, often/ sometimes, seldom, never). The level of job satisfaction was assessed by the response to the question, "How do you feel about your job as a whole?" in which the response was recorded on a fivepoint scale and re-coded dichotomously (strongly disagree, disagree/neutral, agree, strongly agree).

Information regarding gender, marital status, education, and family care workload was also obtained. The number of children under 6 years old and the number of disabled elderly people living with the respondent were used as proxies for family care workloads.

\section{Statistical analysis}

The prevalence of performance-based pay was examined across demographic and employment categories; the differences were assessed with the Chi-square test. Job characteristics, employee's perception of work, and employees' burnout scores under different pay systems were compared and the differences were tested with the Chi-square test (for categorical dependent variables) and the one-way ANOVA test (for continuous dependent variables). For all scales, scores of reversed items were re-ordered in order to make the items additive in the same direction.

Multivariate linear regression analyses were also applied to investigate the independent effects of pay systems on "personal burnout" and "work burnout" scores. Age, marital status, employment grade, family care workload, work hours, shift work, work demands and job control were controlled in the models because these variables were known to predict burnout status and might be associated with pay systems (Ahola et al., 2006; Bultmann, Kant, Kasl, Beurskens, \& van den Brandt, 2002; Jansen, van Amelsvoort, Kristensen, van den Brandt, \& Kant, 2003; Krantz \& Ostergren, 2001; Maslach et al., 2001; Watt et al., 2000). In regression analyses, the scores of job demands and job control were ranked and divided into tertiles (low, medium and high). Since pay systems may influence workers' health through changes in working conditions, controlling job characteristics in regression models may cause an over-control problem. Therefore, we also performed analyses without controlling job characteristics, i.e., with reduced models that included only demographic factors. The results showed that the beta coefficients of pay systems in the reduced model and full model did not differ noticeably (data not shown); thus, only the results of the full model were presented. Variables that measure subjects' perceptions to work, for example, perceived job insecurity, career prospect, etc., were not included in the regression models, because these variables are likely to be intermediate factors in the associations of pay systems and burnout-related health problems. Including these variables in the regression models would lead to an over-control problem.

All statistical analyses were performed with SAS software version 9.1.3 (SAS Institute, 2005). The significance level is 0.05 . Because both adverse psychosocial work factors and health status are known to differ by gender, and it is likely that gender-specific factors such as coping behaviors, social roles, family burdens, socioeconomic conditions might also alter the exposure-outcome associations, all analyses were stratified by gender (Ahola et al., 2006; Vaananen, Buunk, Kivimaki, Pentti, \& Vahtera, 2004).

\section{Results}

Demographic characteristics, job characteristics, employment categories, and burnout scores of the study population are summarized in Table 1 . Of the 15,288 respondents, $41.7 \%$ were female. On the whole, female employees were younger, had a higher educational level, were more likely to be single, tended to work shorter hours, and were less likely to be on shift work than their male counterparts. As for employment grade: we found that manual workers (G5 and G6) accounted for $50.1 \%$ of the male workforce, while non-manual workers accounted for $57.8 \%$ of the female workforce (G3 and G4). Overall, 60\% of the respondents were on a fixed salary, $22.4 \%$ were receiving performance-based pay (with a basic monthly salary), and $17.2 \%$ were receiving piecerate or time-based pay (without a basic salary). The prevalences of performance-based pay and piece-rated/time-based pay were slightly higher in men than in women. One thing to note here is that there are a small number of missing values in marital status and pay system categories. In terms of company size, in this survey, $57 \%$ of the respondents were employed in companies with fewer than 50 workers. Considering burnout measures, women were found to have higher scores of personal burnout and work-related burnout than men.

Table 2 summarizes the distribution of the three categories of pay systems among different demographic and employment groups. In both male and female employees, performance-based pay systems were more prevalent in younger employees, while piece-rate/time-based pay systems were more common among older employees. In terms of educational level, employees with higher educational achievement were more likely to receive performance-based pay, while piece-rate/time-based pay was more prevalent in lower educational groups. In terms of occupational grade, it can be noticed that piece-rate/time-based pays were most common among manual skilled workers. With regard to the industrial sector, piece-rate/time-based pay systems were most prevalent among male construction workers. In terms of company size, performance-based pay was more common in employees of larger companies and piece-rate/time-based pay was more prevalent in employees of smaller companies. Government employees were found to have a higher proportion of fixed pay systems as compared to employees of private sectors.

Table 3 shows the comparison of job characteristics, perceptions of work, and burnout scores among employees with 3 types of pay systems. For both genders, employees earning through performance-based pay reported higher levels of work demands and job 
Table 1

Demographic characteristics, job characteristics and burnout status in both genders $(n=15,288){ }^{\text {a }}$

\begin{tabular}{|c|c|c|c|c|c|}
\hline \multirow[t]{2}{*}{ Variable } & \multicolumn{2}{|c|}{ Men $(n=8906 ; 58.3 \%)$} & \multicolumn{2}{|c|}{ Women $(n=6382 ; 41.7 \%)$} & \multirow[t]{2}{*}{$p$} \\
\hline & $n /$ mean & $(\%) /(\mathrm{sd})$ & $n /$ mean & $(\%) /(s d)$ & \\
\hline \multicolumn{6}{|l|}{ Demographic characteristics } \\
\hline $\begin{array}{l}\text { Age (years) } \\
25-35 \\
35-45 \\
45-55 \\
55-65\end{array}$ & $\begin{array}{l}2991 \\
3098 \\
2215 \\
602\end{array}$ & $\begin{array}{l}(33.6 \%) \\
(34.8 \%) \\
(24.9 \%) \\
(6.8 \%)\end{array}$ & $\begin{array}{l}2489 \\
2244 \\
1386 \\
263\end{array}$ & $\begin{array}{l}(39.0 \%) \\
(35.2 \%) \\
(21.7 \%) \\
(4.1 \%)\end{array}$ & $<0.001$ \\
\hline $\begin{array}{l}\text { Education level } \\
\text { Junior high and below } \\
\text { Senior high } \\
\text { University } \\
\text { Graduate }\end{array}$ & $\begin{array}{l}2536 \\
2960 \\
2947 \\
463\end{array}$ & $\begin{array}{l}(28.5 \%) \\
(33.2 \%) \\
(33.1 \%) \\
(5.2 \%)\end{array}$ & $\begin{array}{l}1539 \\
2182 \\
2430 \\
231\end{array}$ & $\begin{array}{l}(24.1 \%) \\
(34.2 \%) \\
(38.1 \%) \\
(3.6 \%)\end{array}$ & $<0.001$ \\
\hline $\begin{array}{l}\text { Marital status } \\
\text { Single/divorced/separated/widowed } \\
\text { Married/cohabited } \\
\text { Missing }\end{array}$ & $\begin{array}{l}2732 \\
6174 \\
0\end{array}$ & $\begin{array}{l}(30.7 \%) \\
(69.3 \%) \\
(0 \%)\end{array}$ & $\begin{array}{l}2235 \\
4143 \\
4\end{array}$ & $\begin{array}{l}(35.0 \%) \\
(64.9 \%) \\
(0.1 \%)\end{array}$ & $<0.001$ \\
\hline $\begin{array}{l}\text { Family care burden } \\
\text { Number of child living together }(\geqq 1) \\
\text { Number of elder living together }(\geqq 1)\end{array}$ & $\begin{array}{l}2302 \\
1192\end{array}$ & $\begin{array}{l}(25.8 \%) \\
(13.4 \%)\end{array}$ & $\begin{array}{l}1418 \\
699\end{array}$ & $\begin{array}{l}(22.2 \%) \\
(11.0 \%)\end{array}$ & $\begin{array}{l}<0.001 \\
<0.001\end{array}$ \\
\hline $\begin{array}{l}\text { Job characteristics } \\
\text { Pay system } \\
\text { Fixed salary } \\
\text { Performance-based pay (with a basic salary) } \\
\text { Piece-rated/time-based pay (without a basic salary) } \\
\text { Missing }\end{array}$ & $\begin{array}{l}5079 \\
2145 \\
1654 \\
28\end{array}$ & $\begin{array}{l}(57.0 \%) \\
(24.1 \%) \\
(18.6 \%) \\
(0.3 \%)\end{array}$ & $\begin{array}{l}4091 \\
1289 \\
977 \\
25\end{array}$ & $\begin{array}{l}(64.1 \%) \\
(20.2 \%) \\
(15.3 \%) \\
(0.4 \%)\end{array}$ & $<0.001$ \\
\hline $\begin{array}{l}\text { Work hours (hr/week) (range 0-112) } \\
\text { Shift work (yes) } \\
\text { C-JCQ: Work demands (range 12-48) } \\
\text { C-JCQ: Job control (range 24-96) }\end{array}$ & $\begin{array}{l}43.8 \\
1672 \\
30.0 \\
62.3\end{array}$ & $\begin{array}{l}(8.3) \\
(18.8 \%) \\
(3.5) \\
(10.4)\end{array}$ & $\begin{array}{l}42.8 \\
795 \\
29.8 \\
60.7\end{array}$ & $\begin{array}{l}(8.1) \\
(12.5 \%) \\
(3.8) \\
(10.5)\end{array}$ & $\begin{array}{r}<0.001 \\
<0.001 \\
0.001 \\
<0.001\end{array}$ \\
\hline $\begin{array}{l}\text { Employment categories } \\
\text { Employment grade } \\
\text { Grade 1: Administer } \\
\text { Grade 2: Manager or professional } \\
\text { Grade 3: Non-manual skilled } \\
\text { Grade 4: Non-manual low-skilled } \\
\text { Grade 5: Manual skilled } \\
\text { Grade 6: Manual low-skilled }\end{array}$ & $\begin{array}{l}439 \\
817 \\
2040 \\
1149 \\
1834 \\
2627\end{array}$ & $\begin{array}{l}(4.9 \%) \\
(9.2 \%) \\
(22.9 \%) \\
(12.9 \%) \\
(20.6 \%) \\
(29.5 \%)\end{array}$ & $\begin{array}{l}101 \\
806 \\
1430 \\
2261 \\
130 \\
1654\end{array}$ & $\begin{array}{l}(1.6 \%) \\
(12.6 \%) \\
(22.4 \%) \\
(35.4 \%) \\
(2.0 \%) \\
(25.9 \%)\end{array}$ & $<0.001$ \\
\hline $\begin{array}{l}\text { Industry } \\
\text { Manufacturing } \\
\text { Construction } \\
\text { Service } \\
\text { Other }\end{array}$ & $\begin{array}{l}3800 \\
1344 \\
3360 \\
402\end{array}$ & $\begin{array}{l}(42.7 \%) \\
(15.1 \%) \\
(37.7 \%) \\
(4.5 \%)\end{array}$ & $\begin{array}{l}1876 \\
827 \\
3358 \\
321\end{array}$ & $\begin{array}{l}(29.4 \%) \\
(13.0 \%) \\
(52.6 \%) \\
(5.0 \%)\end{array}$ & $<0.001$ \\
\hline $\begin{array}{l}\text { Company size } \\
<10 \\
10-49 \\
50-99 \\
100-499 \\
500+ \\
\text { Government }\end{array}$ & $\begin{array}{l}2660 \\
2473 \\
615 \\
1035 \\
633 \\
1490\end{array}$ & $\begin{array}{l}(29.9 \%) \\
(27.8 \%) \\
(6.9 \%) \\
(11.6 \%) \\
(7.1 \%) \\
(16.7 \%)\end{array}$ & $\begin{array}{l}1798 \\
1778 \\
496 \\
746 \\
403 \\
1161\end{array}$ & $\begin{array}{l}(28.2 \%) \\
(27.9 \%) \\
(7.8 \%) \\
(11.7 \%) \\
(6.3 \%) \\
(18.2 \%)\end{array}$ & 0.008 \\
\hline \multicolumn{6}{|l|}{ Burnout scores } \\
\hline $\begin{array}{l}\text { C-CBI: Personal burnout (range } 0-100) \\
\left.\text { C-CBI: Work-related burnout }{ }^{\mathrm{b}} \text { (range } 0-100\right)\end{array}$ & $\begin{array}{l}34.0 \\
27.9\end{array}$ & $\begin{array}{l}(18.6) \\
(17.6)\end{array}$ & $\begin{array}{l}36.6 \\
29.2\end{array}$ & $\begin{array}{l}(20.3) \\
(18.6)\end{array}$ & $\begin{array}{l}<0.001 \\
<0.001\end{array}$ \\
\hline
\end{tabular}

control, longer working hours, and higher frequency of perceived job stress as compared with workers in the other two pay systems. Piece-rated/time-based pay employees reported lower job control, shorter working hours, higher job insecurity, poorer career prospects, and lower job satisfaction than the other two groups. Concerning the C-CBI burnout scores, employees with fixed pay were found to have the lowest burnout scores among the three groups.

Table 4 presents the results of multiple linear regression analyses of pay systems on personal burnout and work burnout scores, after adjusting for other associated burnout factors, including age, marital status, employment grade, working hours, shift work status, work demands, job control, and the number of children and disabled or elderly people living in the household. As shown in Table 4, among men, employees with either performance-based pay or piece-rated/time-based pay were found to have higher scores of personal burnout and work-related burnout than those with fixed pay. In women, similar results were found, except that women who had piece-rated/time-based pay did not have significantly higher work-related burnout scores. 
Table 2

Distribution of pay systems in different demographic and employment categories.

\begin{tabular}{|c|c|c|c|c|c|c|c|c|c|c|}
\hline \multirow[t]{3}{*}{ Variable } & \multicolumn{5}{|c|}{ Men $(n=8906)$} & \multicolumn{5}{|c|}{ Women $(n=6382)$} \\
\hline & \multicolumn{5}{|c|}{ Pay system } & \multicolumn{5}{|c|}{ Pay system } \\
\hline & $n$ & $\begin{array}{l}\text { Fixed } \\
\text { salary }\end{array}$ & $\begin{array}{l}\text { Performance-based } \\
\text { pay }\end{array}$ & $\begin{array}{l}\text { Piece-rated/ } \\
\text { time-based pay }\end{array}$ & $p$ & $n$ & $\begin{array}{l}\text { Fixed } \\
\text { salary }\end{array}$ & $\begin{array}{l}\text { Performance-based } \\
\text { pay }\end{array}$ & $\begin{array}{l}\text { Piece-rated/ } \\
\text { time-based pay }\end{array}$ & $p$ \\
\hline Age (years) & & & & & $<0.001$ & & & & & $<0.001$ \\
\hline $25-35$ & 2991 & $56.3 \%$ & $29.3 \%$ & $14.4 \%$ & & 2489 & $66.0 \%$ & $25.1 \%$ & $8.9 \%$ & \\
\hline $35-45$ & 3098 & $56.1 \%$ & $24.0 \%$ & $20.0 \%$ & & 2244 & $62.9 \%$ & $18.9 \%$ & $18.3 \%$ & \\
\hline $45-55$ & 2215 & $59.7 \%$ & $19.1 \%$ & $21.2 \%$ & & 1386 & $64.7 \%$ & $15.8 \%$ & $20.2 \%$ & \\
\hline $55-65$ & 602 & $58.6 \%$ & $18.5 \%$ & $23.0 \%$ & & 263 & $60.5 \%$ & $13.3 \%$ & $26.2 \%$ & \\
\hline Education level & & & & & $<0.001$ & & & & & $<0.001$ \\
\hline Junior high and below & 2536 & $45.7 \%$ & $15.2 \%$ & $39.0 \%$ & & 1539 & $49.0 \%$ & $16.3 \%$ & $34.8 \%$ & \\
\hline Senior high & 2960 & $57.3 \%$ & $25.6 \%$ & $17.1 \%$ & & 2182 & $63.9 \%$ & $23.0 \%$ & $13.2 \%$ & \\
\hline University & 2947 & $64.1 \%$ & $30.7 \%$ & $5.2 \%$ & & 2430 & $73.0 \%$ & $20.9 \%$ & $6.2 \%$ & \\
\hline Graduate & 463 & $75.5 \%$ & $22.1 \%$ & $2.4 \%$ & & 231 & $80.4 \%$ & $15.7 \%$ & $3.9 \%$ & \\
\hline Employment grade & & & & & $<0.001$ & & & & & $<0.001$ \\
\hline Grade 1 & 439 & $66.9 \%$ & $29.9 \%$ & $3.2 \%$ & & 101 & $65.4 \%$ & $30.7 \%$ & $4.0 \%$ & \\
\hline Grade 2 & 817 & $74.6 \%$ & $22.9 \%$ & $2.5 \%$ & & 806 & $77.8 \%$ & $18.1 \%$ & $4.1 \%$ & \\
\hline Grade 3 & 2040 & $59.6 \%$ & $33.9 \%$ & $6.6 \%$ & & 1430 & $66.8 \%$ & $23.1 \%$ & $10.2 \%$ & \\
\hline Grade 4 & 1149 & $69.9 \%$ & $23.8 \%$ & $6.3 \%$ & & 2261 & $68.1 \%$ & $20.6 \%$ & $11.3 \%$ & \\
\hline Grade 5 & 1834 & $37.3 \%$ & $13.0 \%$ & $49.8 \%$ & & 130 & $35.7 \%$ & $7.0 \%$ & $57.4 \%$ & \\
\hline Grade 6 & 2627 & $56.7 \%$ & $24.0 \%$ & $19.3 \%$ & & 1654 & $52.8 \%$ & $18.9 \%$ & $28.3 \%$ & \\
\hline Industry & & & & & $<0.001$ & & & & & $<0.001$ \\
\hline Manufacturing & 3800 & $53.5 \%$ & $26.5 \%$ & $20.0 \%$ & & 1876 & $59.2 \%$ & $22.2 \%$ & $18.6 \%$ & \\
\hline Construction & 1344 & $46.0 \%$ & $24.2 \%$ & $29.9 \%$ & & 827 & $65.6 \%$ & $24.5 \%$ & $9.9 \%$ & \\
\hline Service & 3360 & $66.4 \%$ & $22.1 \%$ & $11.5 \%$ & & 3358 & $68.2 \%$ & $18.6 \%$ & $13.2 \%$ & \\
\hline Other & 402 & $52.9 \%$ & $19.6 \%$ & $27.6 \%$ & & 321 & $55.0 \%$ & $27.3 \%$ & $17.7 \%$ & \\
\hline Company size & & & & & $<0.001$ & & & & & $<0.001$ \\
\hline$<10$ & 2660 & $42.4 \%$ & $16.4 \%$ & $41.2 \%$ & & 1798 & $54.3 \%$ & $16.7 \%$ & $29.0 \%$ & \\
\hline $10-49$ & 2473 & $56.7 \%$ & $26.3 \%$ & $17.1 \%$ & & 1778 & $63.0 \%$ & $20.9 \%$ & $16.1 \%$ & \\
\hline $50-99$ & 615 & $64.2 \%$ & $29.9 \%$ & $5.9 \%$ & & 496 & $61.3 \%$ & $28.5 \%$ & $10.1 \%$ & \\
\hline $100-499$ & 1035 & $60.3 \%$ & $34.7 \%$ & $5.0 \%$ & & 746 & $60.0 \%$ & $32.2 \%$ & $7.8 \%$ & \\
\hline $500+$ & 633 & $56.8 \%$ & $41.9 \%$ & $1.3 \%$ & & 403 & $68.4 \%$ & $29.6 \%$ & $2.0 \%$ & \\
\hline Government & 1490 & $79.6 \%$ & $17.3 \%$ & $3.0 \%$ & & 1161 & $84.7 \%$ & $10.5 \%$ & $4.8 \%$ & \\
\hline
\end{tabular}

\section{Discussion}

The results from this study indicated that in men, $57 \%$ of employees were given a fixed salary, $24 \%$ were given a performance-based pay (with a basic salary), and $19 \%$ were remunerated through a piece-rated or time-based pay (without a basic salary). In women, the distributions of the 3 pay systems were $64 \%, 20 \%$ and $15 \%$, respectively. In other words, $82 \%$ of Taiwanese employees (derived from the combined sample of men and women, not shown in table) have a regular basic salary in their pay structures, at least to a certain extent. Information for international comparison is very limited, but the prevalence found in this study appears to be far lower than that reported in the 2005 European working conditions survey (European Foundation for the Development of Living and Working Conditions, 2006), in which the prevalence of regular base pay among employees in the EU25 countries was more than $95 \%$. This finding suggested that pay instability was more prevalent in Taiwanese employees than employees in the European countries. As a newly developed country, Taiwan's government has made economic development as top policy priority and has invested little to social protection for workers against employment instability. The labor force in Taiwan is also largely not unionized and lacking in collective power. It is noteworthy that piece-rate payment has been a controversial labor issue in many developed countries. However, relatively few studies have explored the psychosocial work conditions as well as their impacts on health in working populations of less developed countries. In Sweden, this kind of pay system was highly regulated and was permitted only under certain circumstances, because it represented a form of inappropriate control and was considered to be associated with job strain (Landy, Quick, \&
Kasl, 1994; Smucker, van den Berg, Smith, \& Masi, 1998). By contrast, the potential health costs of variable pay claims may be more significant in countries with weak social protection systems and collective bargaining power for flexible workers, such as Taiwan.

Substantial differences in socio-demographic characteristics and work-related factors among the 3 pay systems could be explained by the strategic objectives of such pay designs (Kurdelbusch, 2002; Lawler, 1990). In this study, we found that as compared with those with fixed pay, workers with performance-based pay were more likely to be younger, with higher educational level and employment grade. These findings suggested that performance-based pay with a regular basic salary was more likely to be introduced to employees with higher human capital or to those who serve core functions within organizations. Performance-based pay was also more common in larger companies than in smaller companies. This finding was consistent with that of a previous study (Cowling, 2002) and was to be expected, since setting up such pay systems often involves intensive management and performance appraisal procedures and is more cost-effective in larger companies. We also found that employees with performance-based pay reported higher work demands, higher job control, and higher frequency of job stress. These findings were in line with previous studies, in which workers with performance-based pay were found to have greater autonomy over their work tasks, increased sense of ownership, and higher levels of commitment toward work (Cowling, 2001; Lawler, 1990; Pendleton, Wilson, \& Wright, 1998). Such types of pay systems encourage competition and entail a firm level of control for performance evaluation, which in turn generates stress responses among workers. 
Table 3

Psychosocial work characteristics, and burnout scores among employees of different pay systems.

\begin{tabular}{|c|c|c|c|c|c|c|c|c|c|c|c|c|c|c|}
\hline \multirow[t]{4}{*}{ Variable } & \multicolumn{7}{|l|}{ Men } & \multicolumn{7}{|c|}{ Women } \\
\hline & \multicolumn{7}{|c|}{ Pay system } & \multicolumn{7}{|c|}{ Pay system } \\
\hline & \multicolumn{2}{|c|}{$\begin{array}{l}\text { Fixed salary } \\
(n=5079)\end{array}$} & \multicolumn{2}{|c|}{$\begin{array}{l}\text { Performance- } \\
\text { based pay } \\
(n=2145)\end{array}$} & \multicolumn{2}{|c|}{$\begin{array}{l}\text { Piece-rated/ } \\
\text { time-based pay } \\
(n=1654)\end{array}$} & \multirow[t]{2}{*}{$p$} & \multicolumn{2}{|c|}{$\begin{array}{l}\text { Fixed salary } \\
(n=4091)\end{array}$} & \multicolumn{2}{|c|}{$\begin{array}{l}\text { Performance- } \\
\text { based pay } \\
(n=1289) \\
\end{array}$} & \multicolumn{2}{|c|}{$\begin{array}{l}\text { Piece-rated/ } \\
\text { time-based pay } \\
(n=977)\end{array}$} & \multirow[t]{2}{*}{$p$} \\
\hline & $\begin{array}{l}n / \\
\text { mean }\end{array}$ & $(\% / s d)$ & $\begin{array}{l}n / \\
\text { mean }\end{array}$ & $(\% / s d)$ & $\begin{array}{l}n / \\
\text { mean }\end{array}$ & $(\% / s d)$ & & $\begin{array}{l}n / \\
\text { mean }\end{array}$ & $(\% / s d)$ & $\begin{array}{l}n / \\
\text { mean }\end{array}$ & $(\% / s d)$ & $\begin{array}{l}n / \\
\text { mean }\end{array}$ & $(\% / s d)$ & \\
\hline \multicolumn{15}{|l|}{ Job characteristics } \\
\hline C-JCQ: Work demands & 29.8 & $(3.6)$ & 30.5 & $(3.6)$ & 30.0 & $(3.2)$ & $<0.001$ & 29.7 & $(3.8)$ & 30.5 & $(3.9)$ & 29.6 & $(3.6)$ & $<0.001$ \\
\hline C-JCQ: Skill discretion & 31.1 & $(5.6)$ & 31.7 & $(5.5)$ & 29.6 & $(5.7)$ & $<0.001$ & 30.2 & $(5.5)$ & 30.7 & $(5.4)$ & 28.6 & $(6.1)$ & $<0.001$ \\
\hline C-JCQ: Decision authority & 31.4 & $(6.1)$ & 32.0 & $(6.3)$ & 30.3 & $(6.1)$ & $<0.001$ & 30.5 & $(6.3)$ & 30.8 & $(6.4)$ & 29.9 & $(6.3)$ & 0.003 \\
\hline $\begin{array}{l}\text { C-JCQ: Job control } \\
(=\text { skill + decision })\end{array}$ & 62.5 & $(10.5)$ & 63.7 & $(10.6)$ & 60.0 & $(10.7)$ & $<0.001$ & 60.8 & $(10.5)$ & 61.5 & $(10.5)$ & 58.5 & $(11.4)$ & $<0.001$ \\
\hline Working hours (hr/week) & 44.1 & $(7.6)$ & 45.1 & $(7.0)$ & 41.2 & $(11.1)$ & $<0.001$ & 42.7 & $(7.4)$ & 44.3 & $(7.1)$ & 41.4 & $(11.0)$ & $<0.001$ \\
\hline Working hours $\geq 49$ & 617 & $(12.2 \%)$ & 308 & $(14.4 \%)$ & 202 & $(12.2 \%)$ & 0.029 & 305 & $(7.5 \%)$ & 156 & $(12.1 \%)$ & 121 & $(12.4 \%)$ & $<0.001$ \\
\hline \multicolumn{15}{|l|}{ Perceptions of work } \\
\hline Job insecurity (high) & 2567 & $(50.6 \%)$ & 1104 & $(51.5 \%)$ & 1274 & $(77.2 \%)$ & $<0.001$ & 2098 & $(51.3 \%)$ & 711 & $(55.2 \%)$ & 772 & (79.1\%) & $<0.001$ \\
\hline Career prospect (low) & 3343 & (65.9\%) & 1341 & $(62.6 \%)$ & 1312 & (79.5\%) & $<0.001$ & 2880 & $(70.5 \%)$ & 879 & $(68.3 \%)$ & 788 & (81.0\%) & $<0.001$ \\
\hline Self-rated job stress (high) & 935 & $(18.5 \%)$ & 553 & $(25.8 \%)$ & 223 & $(13.5 \%)$ & $<0.001$ & 696 & $(17.1 \%)$ & 349 & $(27.2 \%)$ & 163 & $(16.7 \%)$ & $<0.001$ \\
\hline Job satisfaction (high) & 2483 & $(50.1 \%)$ & 1023 & $(49.1 \%)$ & 408 & $(25.3 \%)$ & $<0.001$ & 2158 & $(53.9 \%)$ & 641 & $(51.0 \%)$ & 323 & $(33.8 \%)$ & $<0.001$ \\
\hline \multicolumn{15}{|l|}{ Burnout scores } \\
\hline C-CBI: Personal burnout & 32.6 & $(18.3)$ & 35.8 & $(18.7)$ & 35.8 & $(19.1)$ & $<0.001$ & 35.5 & $(19.9)$ & 39.5 & $(21.2)$ & 37.8 & $(20.6)$ & $<0.001$ \\
\hline C-CBI: Work burnout & 26.9 & $(17.6)$ & 29.4 & $(17.6)$ & 29.1 & $(17.6)$ & $<0.001$ & 28.2 & $(18.3)$ & 32.5 & (19.3) & 29.1 & $(18.3)$ & $<0.001$ \\
\hline
\end{tabular}

${ }^{*} p<0.05 ;{ }^{* *} p<0.01 ;{ }^{* * *} p<0.001$.

On the other hand, employees with piece-rated or time-based pay were more likely to be older, with lower educational levels, employed as manual workers and in smaller companies; and their work were more likely to be characterized by lower job control, poor career prospects and higher job insecurity. It had been found that piece-rated work often had a measurable performance output and a repetitive cycle of operation (Cox, 1985; Kanawaty, 1992; Shirom, 1999). Such types of work were prone to stress-related health problems. As workers with lower socio-economic conditions and those who were employed in smaller companies have already been at greater risks for occupational safety and health problems, income and employment insecurity associated with piece-rated or time-based pay systems might further worsen social inequalities in health in the workplace.

In terms of health status, employees earning through piecerated, time-based, or other performance-based pays were found to have higher levels of personal burnout and work-related burnout, as compared with those earning through fixed salary. The associations held even after the adjustment of social, demographic and work-related factors. Similar associations were found in both genders, except that women earning through pieced-rated/timebased pays did not seem to have higher risk for burnout. This could be explained by gender differences in social roles and social expectation toward work. In Taiwan, women's labor participation rate is much lower than men (47.7\% vs. $67.8 \%$ in 2004$)$. Women might be less threatened by employment instability than men, because they are less likely to be considered as the main bread earners for the family. Patterns of the two C-CBI subscales 'personal burnout' and 'work-related burnout' were similar, and these two subscales were highly correlated, as indicated in our previous validation study (Yeh et al., 2007); it seems that the two measures shared overlapping concept. This could be explained by the centrality of work among our study subjects - most of them were full-time workers and the average working hour was $43 \mathrm{~h}$ per week. Because work constitutes a major part of daily life, it would be difficult to separate burnout problems specifically caused by work from that caused by other domains of life. Our findings about higher burnout status among workers with variable pays echoed those of previous studies among industry-specific workers and blue-collar workers (Schleifer \& Okogbaa, 1990; Shirom, 1999), indicating that the design of a pay system was an important risk factor in workers' stress-related health problems.

There were some limitations in this study. First, the measure for pay systems was crude and the actual amount of pay was not assessed. Future studies should explore the complexity of pay systems and develop a better classification and measurement tool. However, in many social surveys, questions about pay level or income are often regarded as very sensitive topics and associated with non-responses or biased estimates, so validity of these questions are hard to check. It could be argued that the measure of pay system was based on self-report. Because pay system is an objective measure and is often perceived to be less sensitive than the actual amount of pay, there is no sufficient evidence to doubt the validity of the pay system measure. Perceptions and experiences with regard to pay and pay systems-such as perception of fairness (Brown \& Benson, 2003; Gabris, 2001), arousal reaction from performance monitoring (Landy et al., 1994; Schleifer \& Okogbaa, 1990) and actual arrangements of pay-were not assessed, either. Thus causal interpretation linking pay systems with health would be limited. A broad measure of "job satisfaction" was included in our study, but it was not regarded as a principal mediator of the effects of pay systems on employees' health because different components of pay design may lead to different employee perceptions. For example, one may be satisfied with one's salary level but dissatisfied with the operation of the pay system (Miceli, 2000). Moreover, we lacked information regarding the contextual factors accompanying the operation of pay systems in organizations, such as employees' participation, employer-employee relationship and work climate, as well as external social security provisions that may mediate the effects of pay systems on employees' health. Better assessment for pay systems and related indicators in the workplace should be developed in order to advance research on this topic.

In this study, the internal consistency for the 5-item job demands subscale was low ( 0.31 for men, 0.39 for women). Low internal consistency for the same JCQ work demands subscale was 
Table 4

Multivariate-adjusted beta coefficients of pay systems on burnout scores stratified by gender.

\begin{tabular}{|c|c|c|c|c|c|c|c|c|c|c|c|c|}
\hline \multirow[t]{3}{*}{ Independent variable } & \multicolumn{6}{|c|}{ Men $(n=8906)$} & \multicolumn{6}{|c|}{ Women $(n=6382)$} \\
\hline & \multicolumn{3}{|c|}{ Personal burnout } & \multicolumn{3}{|c|}{ Work-related burnout } & \multicolumn{3}{|c|}{ Personal burnout } & \multicolumn{3}{|c|}{ Work-related burnout } \\
\hline & Adj.B & $p$ & $(95 \%$ CI) & Adj.B & $p$ & $(95 \% C I)$ & Adj.B & $p$ & $(95 \% C I)$ & Adj.B & $p$ & $(95 \% C I)$ \\
\hline \multicolumn{13}{|l|}{ Pay system } \\
\hline Fixed salary & 0 & & & 0 & & & 0 & & & 0 & & \\
\hline Performance-based pay & 1.95 & $<0.001$ & $(1.04,2.85)$ & 1.40 & 0.001 & $(0.54,2.26)$ & 2.60 & $<0.001$ & $(1.38,3.82)$ & 2.75 & $<0.001$ & $(1.63,3.87)$ \\
\hline Piece-rate/time-based pay & 2.85 & $<0.001$ & $(1.79,3.90)$ & 1.78 & $<0.001$ & $(0.78,2.78)$ & 2.34 & 0.001 & $(0.91,3.77)$ & 0.92 & 0.166 & $(-0.39,2.24)$ \\
\hline \multicolumn{13}{|l|}{ Age (years) } \\
\hline $25-35$ & 0 & & & 0 & & & 0 & & & 0 & & \\
\hline $35-45$ & -0.12 & 0.817 & $(-1.12,1.88)$ & -0.64 & 0.182 & $(-1.59,0.30)$ & 1.29 & 0.035 & $(0.09,2.49)$ & -0.69 & 0.220 & $(-1.79,0.41)$ \\
\hline $45-55$ & -1.18 & 0.048 & $(-2.35,-0.01)$ & -2.07 & $<0.001$ & $(-3.18,0.96)$ & -0.80 & 0.266 & $(-2.22,0.61)$ & -2.55 & $<0.001$ & $(-3.85,-1.25)$ \\
\hline $55-65$ & -4.04 & $<0.001$ & $(-5.72,-2.37)$ & -4.02 & $<0.001$ & $(-5.60,-2.43)$ & -0.46 & 0.718 & $(-2.99,2.06)$ & -3.56 & 0.003 & $(-5.87,-1.25)$ \\
\hline \multicolumn{13}{|l|}{ Marital status } \\
\hline Married/cohabited & 1.51 & 0.003 & $(0.53,2.49)$ & 0.31 & 0.518 & $(-0.62,0.24)$ & -0.01 & 0.983 & $(-1.12,1.09)$ & -0.98 & 0.059 & $(-1.99,0.04)$ \\
\hline Single/divorced/separated/widowed & 0 & & & 0 & & & 0 & & & 0 & & \\
\hline \multicolumn{13}{|l|}{ Employment grade } \\
\hline $\mathrm{G} 1 / \mathrm{G} 2$ & 0.85 & 0.176 & $(-0.38,2.07)$ & 0.82 & 0.164 & $(-0.34,1.98)$ & 0.63 & 0.469 & $(-1.08,2.34)$ & 0.88 & 0.269 & $(-0.68,2.45)$ \\
\hline $\mathrm{G} 3 / \mathrm{G} 4$ & -0.43 & 0.339 & $(-1.30,0.45)$ & 0.10 & 0.819 & $(-0.73,1.93)$ & -1.15 & 0.058 & $(-2.35,0.04)$ & -1.32 & 0.018 & $(-2.41,-0.23)$ \\
\hline G5/G6 & 0 & & & 0 & & & 0 & & & 0 & & \\
\hline \multicolumn{13}{|l|}{ Work hours (hr/week) } \\
\hline$<49$ & 0 & & & 0 & & & 0 & & & 0 & & \\
\hline$\geqq 49$ & 2.01 & $<0.001$ & $(0.89,3.13)$ & 1.21 & 0.025 & $(0.15,2.27)$ & 1.27 & 0.131 & $(-0.38,2.92)$ & 0.83 & 0.282 & $(-0.68,2.34)$ \\
\hline \multicolumn{13}{|l|}{ Shift work } \\
\hline No & 0 & & & 0 & & & 0 & & & 0 & & \\
\hline Yes & 1.36 & 0.006 & $(0.39,2.32)$ & 2.02 & $<0.001$ & $(1.10,2.94)$ & 0.81 & 0.280 & $(-0.66,2.29)$ & 1.56 & 0.024 & $(0.20,2.91)$ \\
\hline \multicolumn{13}{|l|}{ Work demands } \\
\hline Low (12-28) & 0 & & & 0 & & & 0 & & & 0 & & \\
\hline Median (29-31) & 5.19 & $<0.001$ & $(4.28,6.11)$ & 5.24 & $<0.001$ & $(4.37,6.11)$ & 5.73 & $<0.001$ & $(4.57,6.88)$ & 5.59 & $<0.001$ & $(4.53,6.65)$ \\
\hline High (32-48) & 13.42 & $<0.001$ & $(12.47,14.36)$ & 12.64 & $<0.001$ & $(11.75,13.54)$ & 16.49 & $<0.001$ & $(15.33,17.66)$ & 14.87 & $<0.001$ & $(13.80,15.93)$ \\
\hline \multicolumn{13}{|l|}{ Job control } \\
\hline Low (24-56) & 0 & & & 0 & & & 0 & & & 0 & & \\
\hline Median (58-66) & 0.50 & 0.279 & $(-0.41,1.41)$ & 0.42 & 0.334 & $(-0.44,1.28)$ & 0.89 & 0.117 & $(-0.22,2.01)$ & -0.07 & 0.893 & $(-1.10,0.96)$ \\
\hline High (68-96) & -0.45 & 0.379 & $(-1.45,0.55)$ & -2.29 & $<0.001$ & $(-3.23,-1.34)$ & 1.50 & 0.021 & $(0.22,2.79)$ & -1.19 & 0.046 & $(-2.37,-0.02)$ \\
\hline \multicolumn{13}{|l|}{ Number of child living together } \\
\hline None & 0 & & & 0 & & & 0 & & & 0 & & \\
\hline$\geq 1$ & 1.41 & 0.483 & $(0.48,2.34)$ & 0.51 & 0.261 & $(-0.38,1.39)$ & 2.92 & $<0.001$ & $(1.69,4.15)$ & 2.02 & $<0.001$ & $(0.90,3.15)$ \\
\hline \multicolumn{13}{|l|}{ Number of elder living together } \\
\hline None & 0 & & & 0 & & & 0 & & & 0 & & \\
\hline$\geq 1$ & 1.58 & 0.476 & $(0.48,2.67)$ & 1.55 & 0.004 & $(0.51,2.59)$ & 0.67 & 0.385 & $(-0.84,2.18)$ & 0.78 & 0.270 & $(-0.61,2.17)$ \\
\hline
\end{tabular}

also found in other populations (Cheng et al., 2003; Jian, Wenjie, Ping, Zhefeng, \& Sung-Il, 2004; Karasek et al., 1998; Kawakami, Kobayashi, Araki, Haratani, \& Furui, 1995), indicating that this subscale was problematic and should be improved.

In addition, about $19 \%$ of selected subjects failed to participate in this survey, the representativeness of the study sample might be questionable.

Lastly, we cannot rule out the possibility that the observed associations between pay systems and health might be confounded by factors that were not measured in this study. For example, one may argue that, as compared with those with fixed pays, people who entered piece-rated pay systems might be more likely to have unfavorable coping behaviors, unhealthy lifestyles, inadequate living conditions, or negative personality traits. The observed associations might even be reversed, i.e., unhealthy workers were drifted to unfavorable working conditions. However, considering the centrality of work in adult life and the fact that quality of work strongly influences personal behaviors and material conditions, it could be argued that these factors might also be the consequences of variable pay systems. Regardless of the direction of causation, the co-existence of disadvantaged working conditions and poor health still deserves attention from a public health perspective.
Despite of the mentioned limitations above, this study still provides important information about the distribution of pay systems, and it documents the association of pay systems with employees' burnout status among representative employees from a wide range of occupations and industries.

The findings of this study indicated that performance-based pay systems were common in Taiwan and were frequently associated with disadvantaged work situations and increased levels of personal and work-related burnout. Workplace health promotion programs have not yet paid enough attention to the adverse health effects of such organizational factors. As flexible pay designs have been widely advocated, findings from this study call for more attention to the tradeoff between the widely discussed management advantages and the health burden they place on employees.

\section{References}

Ahola, K., Honkonen, T., Isometsa, E., Kalimo, R., Nykyri, E., Koskinen, S., et al. (2006). Burnout in the general population: results from the Finnish health 2000 study. Social Psychiatry \& Psychiatric Epidemiology, 41(1), 11-17.

Borritz, M., \& Kristensen, T. S. (2001). Copenhagen burnout inventory: Normative data from a representative Danish population on personal burnout and results from the puma study on personal burnout, work burnout, and client burnout. Copenhagen 
National Institute of Occupational Health. from the World Wide Web. http:// www.ami.dk/upload/udgivelser/cbi_data_uk.pdf Retrieved January 25, 2008.

Brown, M., \& Benson, J. (2003). Rated to exhaustion? Reactions to performance appraisal processes. Industrial Relations Journal, 34(1), 67-81.

Bultmann, U., Kant, I., Kasl, S. V., Beurskens, A. J., \& van den Brandt, P. A (2002). Fatigue and psychological distress in the working population: psychometrics, prevalence, and correlates. Journal of Psychosomatic Research 52(6), 445-452.

Burawoy, M. (1979). Manufacturing consent: Changes in the labor process under monopoly capitalism. Chicago: University of Chicago Press.

Cheng, Y., Chen, C. W., Chen, C. J., \& Chiang, T. L. (2005). Job insecurity and its association with health among employees in the Taiwanese general population. Social Science \& Medicine, 61(1), 41-52.

Cheng, Y., Luh, W. M., \& Guo, Y. L. (2003). Reliability and validity of the Chinese version of the Job Content Questionnaire in Taiwanese workers. International Journal of Behavioral Medicine, 10(1), 15-30.

Cowling, M. (2000). Performance related pay in Belgium and the Netherlands. Applied Economics Letters, 7(10), 653-657.

Cowling, M. (2001). Fixed wages or productivity pay: evidence from 15 EU countries. Small Business Economics, 16(3), 191-204.

Cowling, M. (2002). The extent and determination of performance related pay systems in Scandinavian countries. Applied Economics, 34, 305-316.

Cox, T. (1985). Repetitive work: occupational stress and health. In C. L. Cooper, \& M. J. Smith (Eds.), Job stress and blue collar work. New York: John Wiley \& Sons.

European Foundation for the Development of Living and Working Conditions. (2006). Fourth European working conditions surveys 2005. from the World Wide Web. http://www.eurofound.eu.int/pubdocs/2006/78/en/1/ef0678en.pdf Retrieved November 12, 2007.

Gabris, G. T. (2001). Does performance appraisal contribute to heightened levels of employee burnout? The results of one study. Public Personnel Management, $30(2), 157-172$

Hansen, F. (2006). Currents in compensation and benefits. Compensation and Benefits Review, 38(2), 6-19.

Howard, L. W. (2004). Alternative reward strategies and employee reactions. Compensation \& Benefits Review, 36(1), 41-51.

Jansen, N. W., van Amelsvoort, L. G., Kristensen, T. S., van den Brandt, P. A., \& Kant, I. J. (2003). Work schedules and fatigue: a prospective cohort study. Occupational \& Environmental Medicine, 1(Suppl. 60), i47-i53.

Jian, L., Wenjie, Y., Ping, L., Zhefeng, X., \& Sung-Il, C. (2004). Psychometric evaluation of the Chinese (Mainland) version of Job Content Questionnaire: a study in university hospitals. Industrial Health, 42(2), 260-267.

Kaminski, M. (2001). Unintended consequences: organizational practices and their impact on workplace safety and productivity. Journal of Occupational Health Psychology, 6(2), 127-138.

Kanawaty, G. (1992). Introduction to work study. Geneva: International Labor Organization.

Karasek, R., Brisson, C., Kawakami, N., Houtman, I., Bongers, P., \& Amick, B. (1998). The Job Content Questionnaire (JCQ): an instrument for internationally comparative assessments of psychosocial job characteristics. Journal of Occupational Health Psychology, 3(4), 322-355.

Karasek, R., \& Theorell, T. (1990). Healthy work. Stress, productively, and the reconstruction of working life. New York: Basic Books.

Kawakami, N., Kobayashi, F., Araki, S., Haratani, T., \& Furui, H. (1995). Assessment of job stress dimensions based on the job demands-control model of employees of telecommunication and electric power companies in Japan: reliability and validity of the Japanese Version of the Job Content Questionnaire. International Journal of Behavioral Medicine, 2(4), 358-375.
Krantz, G., \& Ostergren, P. O. (2001). Double exposure: the combined impact of domestic responsibilities and job strain on common symptoms in employed Swedish women. European Journal of Public Health, 11(4), 413-419.

Kristensen, T. S., Borritz, M., Villadsen, E., \& Christensen, K. B. (2005). The Copenhagen burnout inventory: a new tool for the assessment of burnout. Work and Stress, 19(3), 192-207.

Kurdelbusch, A. (2002). Multinationals and the rise of variable pay in Germany. European Journal of Industrial Relations, 8(3), 325-349.

Landsbergis, P. A., Cahill, J., \& Schnall, P. (1999). The impact of lean production and related new systems of work organization on worker health. Journal of Occupational Health Psychology, 4(2), 108-130.

Landy, F., Quick, J. C., \& Kasl, S. (1994). Work, stress, and well-being. International Journal of Stress Management, 1(1), 33-73.

Lawler, E. E. (1990). Strategic pay. San Francisco: Jossey-Bass.

Maslach, C., Schaufeli, W. B., \& Leiter, M. P. (2001). Job burnout. Annual Review of Psychology, 52, 397-422.

Mayhew, C., Quintan, M., \& Ferris, R. (1997). The effects of subcontracting/ outsourcing on occupational health and safety: survey evidence from four Australian industries. Safety Science, 25(1-3), 163-178.

Menendez, M., Benach, J., Muntaner, C., Amable, M., \& O'Campo, P. (2007). Is precarious employment more damaging to women's health than men's? Social Science E Medicine, 64(4), 776-781.

Miceli, M. P. (2000). Consequences of satisfaction with pay systems: two field studies. Industrial Relations, 39(1), 62-87.

Pendleton, A., Wilson, M., \& Wright, M. (1998). The perceptions and effects of share ownership: empirical evidence from employee buyouts. British Journal of Industrial Relations, 36(1), 99-123.

SAS Institute. (2005). SAS/STAT User's Guide, Version 9.1.3. Cary, NC: SAS Institute.

Schabracq, M. J., \& Cooper, C. L. (1997). Flexibility of labor, well-Being, and stress. International Journal of Stress Management, 4(4), 259-274.

Schleifer, L. M., \& Okogbaa, O. G. (1990). System response time and method of pay: cardiovascular stress effects in computer-based tasks. Ergonomics, 33(12), 1495-1509.

Shirom, A. (1999). The effects of pay systems on blue-collar employees' emotional distress: the mediating effects of objective and subjective work monotony. Human Relations, 52(8), 1077-1095.

Shirom, A., Melamed, S., Toker, S., Berliner, S., \& Shapira, I. (2005). Burnout and health: current knowledge and future research directions. International Review of Industrial and Organizational Psychology, 20, 269-309.

Small and Medium Enterprise Administration, Ministry of Economic Affairs, Taiwan. (2006). Taiwan's economic development. from the World Wide Web. http://www. moeasmea.gov.tw/ct.asp? $x$ Item $=72 \& C$ tNode $=263 \& m p=1$ Retrieved October 16 , 2008.

Smucker, J., van den Berg, A., Smith, M. R., \& Masi, A. C. (1998). Labor deployment in plants in Canada and Sweden. Industrial Relations, 53(3), 430-457.

Vaananen, A., Buunk, B. P., Kivimaki, M., Pentti, J., \& Vahtera, J. (2004). When is it better to give than to receive: long-term health effects of perceived reciprocity in support exchange. Journal of Personality and Social Psychology, 89, 176-193.

Watson Wyatt. (2005). Strategic rewards and pay practices: Advancing the total rewards perspective. Washington, DC: Watson Wyatt Worldwide.

Watt, T., Groenvold, M., Bjorner, J. B., Noerholm, V., Rasmussen, N. A., \& Bech, P. (2000) Fatigue in the Danish general population: influence of sociodemographic factors and disease. Journal of Epidemiology E Community Health, 54(11), 827-833.

Yeh, W. Y., Cheng, Y., Chen, C. J., Hu, P. Y., \& Kristensen, T. S. (2007). Psychometric properties of the Chinese version of Copenhagen burnout inventory among employees in two companies in Taiwan. International Journal of Behavioral Medicine, 14(3), 126-133. 